\title{
JOURNAL.RU
}

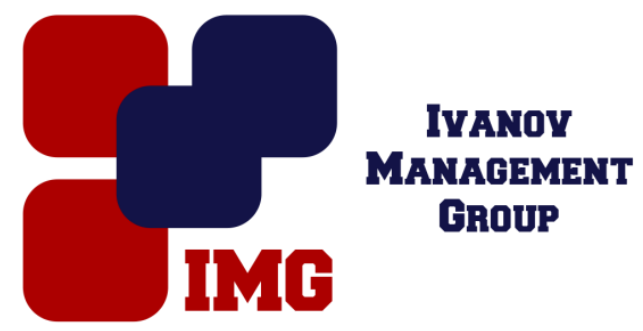

Дурнова Н.А., Березуцкий М.А., Васина А.С.

Саратовский государственный медицинский университет им. В.И. Разумовского Саратов, Россия

doi: $10.18411 / 1 \mathrm{j}-31-07-2017-21$

idsp 000001:1j-31-07-2017-21

\section{Биологическая активность и применение \\ в медицине недотроги мелкоцветковой}

\section{Аннотация}

Приводится краткий обзор литературы по биологической активности и применению в медицине недотроги мелкоцветковой.

Ключевые слова: Impatiens parviflora, применение в медицине, обзор

Недотрога мелкоцветковая (Impatiens parviflora DC., Balsaminaceae, Magnoliophyta) - однолетнее растение с несколько мясистыми стеблями, простыми цельными листьями и бледно-желтыми зигоморфными цветками [8]. Родиной вида являются Центральная Азия и юг Западной Сибири, где это растение произрастает по берегам рек и ручьев, в ущельях, по каменистым склонам гор, во влажных тенистых местах [11]. В первой половине XIX в. данное растение в качестве адвентивного было обнаружено во многих пунктах Европы, а с середины XX в. ареал I. parviflora в Европе стал быстро расширяться [14]. В последние десятилетия наблюдается интенсивное внедрение н. мелкоцветковой в лесные экосистемы Центральной и Восточной Европы [1]. В Саратовской области н. мелкоцветковая ранее была известна только в Балашовском р-оне [6]. При детальном исследовании около 10 лет назад флоры г. Саратова и его окрестностей этот вид не был выявлен на данной территории [10]. В настоящее время наблюдается массовая натурализация $\mathrm{H}$. мелкоцветковой в лесные экосистемы природного парка «Кумысная поляна» в окр. г. Саратова. В частности, в районе «4 дачной» этот вид является 
доминантом травяного яруса в старовозрастных кленовниках, местами образуя чистые заросли с проективным покрытием около 100\%. Численность особей н. мелкоцветковой в данном пункте столь велика, что можно говорить об определенном ресурсном значении этого вида.

Несмотря на то, что н. мелкоцветковая представляет опасность для природных экосистем, она обладает разнообразными полезными свойствами, которые определяют возможность ее практического применения на новых частях ареала.

Экспериментально показано, что экстракт из листьев этого растения препятствует процессу денатурации белков [15]. В связи с этим н. мелкоцветковая является хорошим природным антидотом и применяется наружно при химических ожогах кожи, вызванных растениями (крапивой, видами сумаха и др.) [18]. Цветки и семена недотроги прикладывают к местам укуса ядовитых змей, а внутрь принимают настой травы этого растения. Экстракт I. parviflora обладает также значительной антимикробной и антиаксидантной активностью [17]. Поэтому он может быть новым источником антиаксидантов для производства пищевых оздоровительных добавок.

Экспериментальными исследованиями также установлено, что препараты н. мелкоцветковой специфически действуют на нервно-мышечный аппарат матки (повышают тонус и увеличивают амплитуду сокращения миометрия) [12]. Настой травы регулирует менструальный цикл, стимулирует роды и останавливает маточные кровотечения. В Узбекистане также применяется как кровоостанавливающее средство [13]. Настой из листьев обладает диуретическим и слабительным действием, применяется при геморрое [7].

Растение обладает фунгицидным действием [2]. В связи с этим в Таджикистане свежие измельченные листья местно применяются при дерматомикозах [3], в частности, для лечения стригущего лишая. Используется также в качестве средства для полоскания волос для облегчения зуда кожи головы [18]. Наружно также применяется при лечении доброкачественных новообразований кожи (бородавок, наростов и т.д.) [18].

Экстракт I. parviflora показал очень высокую реппелентную и инсектицидную активность по отношению к представителям отряда Homoptera (персиковая тля). После 54 ч экспозиции экстракта в 0,5\% концентрации процент смертности составил 99,7\%, а реппелентность в разное время составила 90-100\%. [16]. В связи с этим, возможно, н. мелкоцветковая является перспективным инсектицидным и реппелентным растением по отношению к 
представителям отряда Diptera, включая переносчиков опасных заболеваний $[4,5]$.

Несмотря на то, что растение относится к числу ядовитых [9], молодые листья, сваренные с одной сменой воды, употребляют в пищу; семена являются съедобными в сыром и вареном виде [18].

Необходимо дальнейшее активное исследование полезных свойств н. мелкоцветковой. Широкое практическое применение и массовое изъятие из природы для этих целей большого числа особей н. мелкоцветковой, возможно, будет частично способствовать уменьшению отрицательного воздействия этого вида на естественные экосистемы на новых частях ареала.

$* * *$

1. Березуцкий М.А., Кашин А.С. Антропогенная трансформация флоры и растительности. Учебное пособие. Саратов, 2008, 100 с.

2. Глушакова А.М., Качалкин А.В., Чернов И.Ю. Влияние инвазионных видов травянистых растений на структуру почвенных дрожжевых комплексов смешанного леса на примере Impatiens parviflora DC. // Микробиология. 2015. T. 84, № 5. С. 606-611.

3. Дадобаева О. Словарь научных и местных названий лекарственных растений Северного Таджикистана. Душанбе, 1972. 130 с.

4. Дурнова Н.А. Хирономиды рода Glyptotendipes Kieffer (Diptera, Chironomidae): морфология кариотипы и экологические особенности. Автореф. дис... канд. биол. наук. Санкт-Петербург, 1998. 16 с.

5. Дурнова Н.А. Хирономиды перифитона водоемов Саратовской области: экологические особенности, морфология, цитогенетика. Автореф. дис... докт. биол. наук. СанктПетербург, 2010. 48 с.

6. Еленевский А.Г., Буланый Ю.И., Радыгина В.И. Конспект флоры Саратовской области. Саратов, 2008. 232 c.

7. Лавренова Г. В., Лавренов В. К. Энциклопедия лекарственных растений. Т. 1. Донецк, 1997. T. $1.655 \mathrm{c}$.

8. Мордак Е.В. Сем. Balsaminaceae A. Rich. - Бальзаминовые // Флора Восточной Европы. T. 9. СПб, 1996. С. $390-392$.

9. Орлов Б.Н., Гелашвили Д.Б., Ибрагимов А.К. Ядовитые животные и растения СССР. М., 1990. $272 \mathrm{c}$.

10. Панин А.В., Березуцкий М.А., Шилова И.В. Конспект флоры города Саратова. Саратов:, $2008,62 \mathrm{c}$.

11. Победимова Е.Г. Сем. Бальзаминовые - Balsaminaceae S.F. Gray. // Флора CCCP. Т. 14. М.-Л., 1949. С. $624-634$.

12. Тукаюте Е.П. Исследование травы недотроги мелкоцветковой и получение из нее галенового препарата. Автореф. дис... канд. фармац. наук. Тарту, 1954. 8 с.

13. Халматов Х.Х. Дикорастущие лекарственные растения Узбекистана. Ташкент, 1964. 278 c. 
14. Coombe D.E. Biological Flora of the British Isles, Impatiens parviflora DC. // Journal of Ecology. 1956. Vol. 44. P. 701-713.

15. Grabowska K., Podolak I., Galanty A., Załuski D1, Makowska-Wąs J., Sobolewska D., Janeczko Z., Żmudzki P. In vitro anti-denaturation and anti-hyaluronidase activities of extracts and galactolipids from leaves of Impatiens parviflora DC. // Natural product research. 2016. Vol. 30 (10). P. $219-223$.

16. Pavela R., Vrchotová N., Sera B. Repellency and toxicity of three Impatiens species(Balsaminaceae) extracts on Myzus persicae Sulzer(Homoptera: Aphididae) // Journal of Biopesticides. 2009. Vol. 1 (2). P. 48 - 51.

17. Szewczyk K., Zidorn Ch., Biernasiuk A., Komsta L., Granica S. Polyphenols from Impatiens (Balsaminaceae) and their antioxidant and antimicrobial activities // Industrial Crops and Products. 2016. Vol. 86. P. 262-272.

18. Schofield J. J. Discovering Wild Plants: Alaska, W. Canada, the Northwest. Bothell, 1989. 354 p. 